\title{
Alumina-Supported Ruthenium Catalysts for the Racemization of Secondary Alcohols
}

\author{
Won-Hee Kim, Ramasamy Karvembu, and Jaiwook Park* \\ National Research Laboratory of Chirotechnologv, Department of Chemistry, Division of Molecular and Life Science, \\ Pohang Lnversity of Science and Technologv, Pohang, Kintngbuk 790-784, Korea
}

Received March 8, 2004

Key Words : Racemization. Ruthenium. Alumina. Secondary alcohols. Reçclable

The resolution of racemic alcohols is a practical approach to the synthesis of enantiomerically pure alcohols on an industrial scale. 'However a major disadvantage of the resolution is the yield limited only to $50 \%$. Hence. racemization of the unwanted enantiomer is desirable for overcoming the disadvantage. Although the dynamic kinetic resolution (DKR) using homogeneous racemization catalysts. in which in situ racemization proceeds during the resolution process has been developed for chiral alcohols and amines. " its application to a large scale production is hindered by the difficulties with the separation of the products from the reaction mixture and the catalyst recycling. "Thus. the development of recyclable catalysts for the racemization of secondary alcohols is an attractive research subject. Acid resins such as Amberlyst 15 and Deloxan are among the rare examples. ${ }^{+}$which. however catalyze only the racemization of benzylic alcohols in aqueous media. Recently Ru(III) immobilized on calcium hydroxyapatite (Ru-HAP) was reported as a heterogeneous catalyst for the racemization of aliphatic alcohols as well as benzylic ones in toluene. ${ }^{5}$ The Ru-HAP. however. retains less than $50 \%$ of its original activity in the second use.

In our efforts to find a recyclable catalyst for the racemization of alcohols. we were attracted to a heterogeneous ruthenium catalyst. which is active for the aerobic oxidation of alcohols. ${ }^{6}$ Herein we report that the ruthenium supported on $\gamma$-alumina $\left(\mathrm{Ru} / \mathrm{Al}_{2} \mathrm{O}_{3}\right)$ is an efficient recyclable catalyst for the racemization of secondary alcohols. For the racemization. it does not require any additive. and is reusable after simple recovery by filtration.

\section{Results and Discussion}

The $\mathrm{Ru} / \mathrm{Al}_{3} \mathrm{O}_{3}$ cataly sts were prepared from $\mathrm{RuCl}_{3}$ and $\gamma$ alumina according to a known procedure ${ }^{6}$ To see the effect of the ruthenium contents on their reactivity. four catalysts were prepared: $1(0.75 \%): 2(1.25 \%): 3(2.37 \%): 4(3.5 \% \mathrm{Ru}$ by weight) ${ }^{7}$ The racemization of (S)-1-pheny lethanol was chosen as a test reaction to compare the activities of 1-4 and a commercial one (5: $5 \% \mathrm{Ru}$ on alumina) (Table 1). $\gamma$ Alumina itself was inactive. and the catalyst 2 showed the highest activity when the amount of $\mathrm{Ru} / \mathrm{Al}_{2} \mathrm{O}_{3}$ employed was adjusted to contain the same molar amount of nuthenium.

Then. to optimize the reaction conditions. the racemization of (S)-1-phenylethanol with 2 was examined with
Table 1. Racemization of (S)-1-phenylethanol with $\mathrm{Ru} / \mathrm{Al}_{2} \mathrm{O}_{3}{ }^{a}$

\begin{tabular}{cccc}
\hline Entry & Catalyst & Yield $(\%)^{b}$ & ee $(\%)^{c}$ \\
\hline 1 & ${ }^{b} \mathrm{Al}_{2} \mathrm{O}_{3}$ & $>99.9$ & 99.0 \\
2 & $\mathbf{1}$ & 90.9 & 10.4 \\
3 & $\mathbf{2}$ & 90.7 & 1.4 \\
4 & $\mathbf{3}$ & 92.0 & 12.4 \\
5 & 4 & 93.0 & 16.1 \\
6 & $\mathbf{5}$ & 95.0 & 61.8 \\
\hline
\end{tabular}

The reactions were carried out with 0.125 mmol (S)-l-phen lethanol and $3.6 \mathrm{~mol}^{\circ}$ of $\mathrm{Ru}_{\mathrm{Al}} \mathrm{A}_{3}$ in $0.5 \mathrm{~mL}$ of dr: and degassed toluene at 70 ${ }^{\circ} \mathrm{C}$ for $5 \mathrm{~h}$ under argon. ${ }^{b}$ Determined by GC (Chiral B-PH). 'Determined by HPLC (Chiralcel OD).

Table 2. Racemization of (S)-1-phenylethanol under various conditions $^{a}$

\begin{tabular}{ccccc}
\hline Entry & Solvent & Temp. $\left({ }^{\circ} \mathrm{C}\right)$ & Yield $(\%)^{b}$ & ee $(\%)^{c}$ \\
\hline 1 & $\mathrm{CH}_{2} \mathrm{Cl} l_{2}$ & 40 & 93.9 & 54.8 \\
2 & Toluene & 40 & 93.1 & 42.1 \\
3 & Toluene & 70 & 90.7 & 1.4 \\
4 & Benzene & 70 & 83.4 & 0.6 \\
5 & $\mathrm{THF}$ & 70 & 91.6 & 8.5 \\
6 & $\mathrm{EtOAc}$ & 70 & 95.1 & 94.4 \\
7 & $\mathrm{H}_{2} \mathrm{O}$ & 70 & 97.7 & 9.8 \\
\hline
\end{tabular}

The reactions were carried out with 0.125 mmol (S)-l-phenvlethanol and $3.6 \mathrm{~mol}^{\circ} \mathrm{s}$ of 2 in $0.5 \mathrm{~mL}$ of dry and degassed toluene for $5 \mathrm{~h}$ under Ar. 'Determined by GC (Chiral B-PH). 'Determined by HPLC (Chiralcel OD).

varing solvent and temperature (Table 2). The rate of the racemization increased with heating: the racemization was complete in $5 \mathrm{~h}$ at $70^{\circ} \mathrm{C}$ in toluene. The yield of the racemic 1-phenylethanol was higher in toluene than in benzene: the formation of acetophenone was greater in benzene. Generally. the racemization was faster in nonpolar solvents than in polar ones. Particulary. the racemization was almost inhibited in water or in ethyl acetate even at $70^{\circ} \mathrm{C}$

The activity of $\mathbf{2}$ was higher than that of Ru-HAP for the racemization of (S)-1-phenylethanol. ${ }^{5}$ In contrast to Ru-HAP that shows less than $50 \%$ of its original activity upon second use. 2 retained more than $50 \%$ of the original activity even in the fourth use (Table 3). Furthermore, washing the recovered catalyst with $1.0 \mathrm{M}$ aqueous $\mathrm{NaOH}$ solution revived the original activity almost completely. Meanwhile the heterogeneous nature of $\mathbf{2}$ was tested by a simple filtration test: the racemization did not proceed in the filtrate when the reaction 
Table 3. Recycling of 2 for the racemization ${ }^{t, h}$

\begin{tabular}{ccll}
\hline Entry & Cycle & \multicolumn{1}{c}{ Yicld $(\%)^{c}$} & $\mathrm{ec}(\%)^{\prime}$ \\
\hline 1 & Ist & 90.7 & 1.0 \\
2 & 2nd & $90.9(91.0)$ & $1.6(19.8)$ \\
3 & 3rd & $90.8(93.6)$ & $1.3(28.0)$ \\
4 & 4th & $91.0(93.7)$ & $2.3(41.9)$ \\
5 & 5th & 91.2 & 6.2 \\
\hline
\end{tabular}

"The reactions were carricd out with $0.125 \mathrm{mmol}(S)$-I-phent lethathol and $3.6 \mathrm{~mol} \%$ of $2 \mathrm{in} 0.5 \mathrm{ml}$. of dry and degassed toluene at $70^{\circ} \mathrm{C}$ for $5 \mathrm{~h}$ under Ar. "The values in parentheses were obtained from the reactions using the calalyst recovered by simple liltration. 'Determined by $\mathrm{GC}$

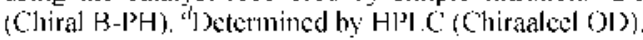

Table 4. Racemization of wartous sccondary alcohols"

\begin{tabular}{|c|c|c|c|c|}
\hline Entry & Substrate & Time (h) & Yield $(\%)^{b}$ & $\overline{e e}(\%)^{c}$ \\
\hline \multirow{2}{*}{1} & & 1 & 91.9 & 47.5 \\
\hline & & 5 & 90.7 & 1.4 \\
\hline \multirow{2}{*}{2} & & 1 & 94.9 & 52.5 \\
\hline & & 8 & 91.0 & 1.3 \\
\hline \multirow{2}{*}{3} & & 1 & 94.6 & 54.8 \\
\hline & & 8 & 90.8 & 2.1 \\
\hline \multirow[b]{2}{*}{4} & & 1 & $95.3^{d}$ & 54.2 \\
\hline & & 8 & $94.9^{d}$ & 5.4 \\
\hline \multirow[b]{2}{*}{5} & & 1 & 93.9 & $50.3^{e}$ \\
\hline & & 8 & 90.0 & $3.3^{e}$ \\
\hline \multirow{2}{*}{6} & & 1 & $87.7^{d}$ & 37.6 \\
\hline & & 3 & $76.2^{d}$ & 0.2 \\
\hline
\end{tabular}

"The reactions were carried out with 0.125 mmol chiral alcohol and 3.6 mol\% of 2 in $0.5 \mathrm{~mL}$ of dry and clegassed toluene at $70^{\circ} \mathrm{C}$ under Ar.

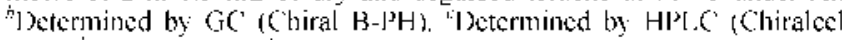
OD). "Determined by 'I I NMR. "Determined by GC after converting to 2-ocly] acelite.

mixture was filtered through a glass filter (pore size: $20-30$ $\mu \mathrm{m})$.

To explore the scope of the catalytic racemization by 2 , a series of secondary alcohols were examined (Table 4). The catalyst was effective for the racemization of aliphatic alcohols as well as benzylic ones. Generally, benzylic alcohols were racemized faster than aliphatic ones: the racemization of $(S)$ 1-phenylethanol was complete in $5 \mathrm{~h}$ at $70^{\circ} \mathrm{C}$ while that of (S)-2-octanol took $8 \mathrm{~h}$. It was notable that the chloride group in the aliphatic chain did not interfere with the catalytic racemization as shown in the case of $(S)$-2-chloro- I-phenylethanol, because its analogues have potential to be used as key building blocks for useful pharmaceuticals. ${ }^{8}$

A pathway for the racemization of secondary alcohols by $\mathrm{Ru}_{\mathrm{A}} \mathrm{Al}_{2} \mathrm{O}_{3}$ is proposed on the basis of the report that describes

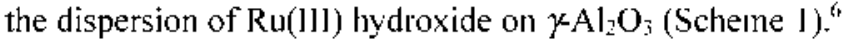
Initially, a Ru-alkoxide species (7) is formed, which undergoes reversible intramolecular hydrogen-transfer reactions
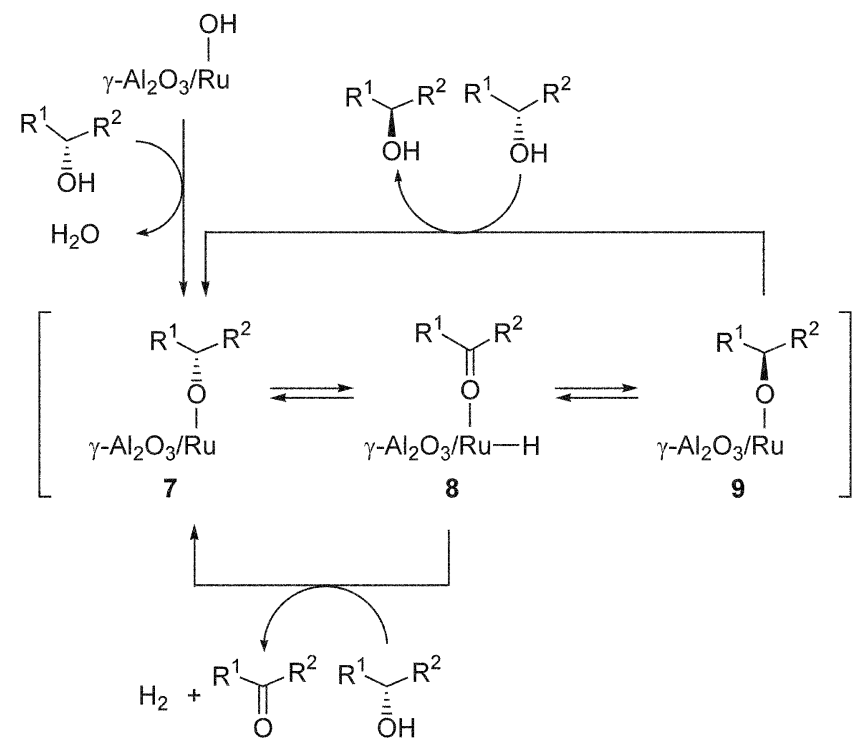

Scheme 1. A proposed pathway for the catalytic racemization of secondary alcohols.

through the $\beta$-H elimination to form a (ketone) $\mathrm{Ru}-\mathrm{H}$ intermediate (8) and the insertion into the $\pi$-bond of the carbonyl group to give the isomeric Ru-alkoxide species (9). Then. the intermolecular exchange of the alkoxy ligand between the alcohol and the alkoxy complexes leads to the racemization. Meanwhile, the reaction of 8 and alcohol can produce molecular hydrogen and 7 or 9 with liberating ketone. This proposed pathway is consistent with the production of acetophenone during the racemization of $(S)$ 1-phenylethanol and with the observation that water inhibits the racemization.

Preliminary attempts to combine lipase-catalyzed acylation with the catalytic racemization by $\mathrm{Ru} / \mathrm{Al}_{2} \mathrm{O}_{3}$ for the DKR of secondary alcohols were not successful. The acyl donors such as $p$-chlorophenyl acetate, vinyl acetate, and isopropenyl acetate inhibited the catalytic racemization. Acetic acid, which would be produced during the DKR, was also an inhibitor. The use of sodium carbonate did not help to overcome the inhibition by the acyl donors and acetic acid.

\section{Conclusions}

We have found that the ruthenium on alumina $\left(\gamma-\mathrm{Al}_{2} \mathrm{O}_{3}\right)$, when the ruthenium content is about $1 \%$ by weight, is an efficient heterogeneous catalyst for the racemization of aliphatic alcohols as well as benzylic ones. The preparative procedure for the catalyst is simple and efficient, and the catalyst maintains its original activity in reuse.

\section{Experimental Section}

The $\mathrm{Ru} / \mathrm{Al}_{2} \mathrm{O}_{3}$ catalysts were prepared according to literature. ${ }^{\text {"The }}$ optically active secondary alcohols employed except the following ones were prepared by enzymatic resolution. ${ }^{9}(S)$-2-Octanol and (S)-2-chloro-1-phenylethanol 
were purchased.

Catalytic racemization of alcohols. (S)-1-Phenylethanol ( $15 \mu \mathrm{L}, 0.125 \mathrm{mumol}$ ) was added to a suspension of $\mathrm{Ru} / \mathrm{Al}_{2} \mathrm{O}_{3}$ (1.25 wt. \% Ru. $36 \mathrm{mg}, 3.6 \mathrm{~mol} \%)$ in toluene $(0.5 \mathrm{~mL})$. The reaction mixture was stirred and heated to $70^{\circ} \mathrm{C}$ under argon. The \% ee was determined by HPLC (Colunun: Chiralcel OD: eluent: $n$-hexane/2-propanol. 95/5). After the reaction, the reaction mixture was filtered through a glass filter $(20-30 \mu \mathrm{m})$, and the products in the filtrate were analyzed by $\mathrm{GC}$ and ${ }^{~} \mathrm{H}$ NMR. The separated catalyst was washed with an aqueous solution of $\mathrm{NaOH}(1.0 \mathrm{M})$ and water. and dried in vacuo before reuse

Acknowledgment. This work was supported by Korea Research Foundation Grant (KRF-2002-005-C00010).

\section{References}

1. (a) Wang. C. H.: Whitesides. G. M. Enzmes in Sinthetic Organic Chemistn: Elsevier: Ansterdam, 1994. (b) Sheldon, R. A. Chirotechnology. Industrial Symbesis of Optically Active Componts: Dekker: New York, 1993. (c) Laumen, K.: Breitgoff. D.: Scluneider. M. P. Chem. Commm. 1988. 1459.

2. (a) Pàmies. O.: Bäckvall. J.-E. Chent. Rev: 2003. 103. 3247. (b)
Pellissier, H. Tetrahedron 2003. 59, 8291. (c) Kim. M.-J; Chung. Y. I.: Choi. Y. K.: Lee. H. K.: Kim. D.: Park. I. J. Am. Chem. Soc. 2003. 125. 11494. (d) Wuyts. S.: Temmerman. K. D.: Vos. D. D.: Jacobs. P. Chent Conmum. 2003. 1928. (e) Kim. M.-.: Ahn. Y.: Park, J. Curr Opin. Biotechnol. 2002. 13, 578. (f) Huerta. F. F. Minidis. A. B. E.: Băckvall. J.-E. Chem. Soc. Ren. 2001. 30. 321.

3. Borman. S. Chemisto \& Engineering Yew's 2002. $80(45), 43$.

4. (a) Kalliney. S. Y.: Ruggeri. M. V. HO Patent. 91008196.1991 (b) House. D. W. LS Patent, 5, 776,96t. 1995.

5. Wuyts. S.: Vos. D. K. D.: Verpoort. F.: Delpa. D.: Gryse. R. D.: Jacobs. P. A. J. Catal. 2003, $219,417$.

6. (a) Yamaguchi, K; Mizuno. N. Chem. Eur d. 2003. 9. 4353 . (b) Yamaguchi. K: Mizuno. N. Angew: Chem. Int. Ed. 2003. 42. 1480. (c) Yamaguchi. K.: Mizuno. N. Angew. Chem. Iht Ed. 2002. H. 4538 .

7. The ruthenium contents were measured by inductively coupled plasma (ICP) analysis, which were deviated from those expected by the employed amounts of $\mathrm{RuCl}_{3}$ and $\gamma$ alumina.

8. (a) Hamada. T.: Torii. T.; Izawa, K: Noyori. R:- Ihariya. T. Org. Lett. 2002. 4. 4373, (b) Pàmies. O.: Bächvall. J-E. J. Org. Chem 2002. 67. 9006 . (c) Uehling. D. E.: Donaldson1. K. H.: Deaton1. D N.: Hyman. C. E.: Sugg. E. E.: Barrett. D. G.: Hughes. R. G.: Reitter. B.; Adkison, K. K.: Lancaster. M. E.; Lee. F.: Hart. H.; Paulik, M. A.; Sherman, B. W. True. T.; Cowman, C. J. Ifed Chem, 2002, 45. 567. (d) Kordik, C. P., Reitz, A. B. J. Hed. Chem. 1999. 42. 181

9. Klibanov. A. M. Acc. Chem. Res. 1990. 23. 114. 